\title{
SIRen: An Applied Framework for a Sustainable Renovation Process
}

\author{
Petter Wallentén ${ }^{1, *}$ and Kristina Mjörnell 1,2,*(D) \\ 1 Department of Building Physics, Lund University, 22100 Lund, Sweden \\ 2 Sustainable Cities and Communities, RISE Research Institutes of Sweden, 41258 Göteborg, Sweden \\ * Correspondence: petter.wallenten@byggtek.lth.se (P.W.); kristina.mjornell@ri.se (K.M.); \\ Tel.: +46-10-516-57-45 (K.M.)
}

\begin{abstract}
The renovation of buildings involves multidisciplinary issues and multistakeholder involvement, which makes the process complex to manage. The purpose of this paper is to present a transparent, openly accessible, adaptable framework to ensure a sustainable renovation process, covering the technical, environmental, economic, social, and cultural historical aspects to be considered by the various actors during the renovation process. A framework with an associated process was drawn up, focusing on practical usefulness together with the fundamental idea that sustainability cannot be a sub requirement but must be the overall requirement present in all stages of the process. The framework contains an overview, description of activities, links to external tools and documents, and finally a checklist to be completed after each stage. Depending on which stakeholder uses the framework, there are different examples and suggestions for activities and tools. Contrary to many other assessment schemes, the SIRen process focuses on the renovation process itself, and the self-evaluation gives a numerical value that represents to what extent the actors have considered and implemented different aspects of sustainability in the stages of the renovation process. The SIRen process was partially implemented in four renovation projects during the iterative development of the SIRen framework.
\end{abstract}

SIRen: An Applied Framework for a Sustainable Renovation Process. Sustainability 2021, 13, 5412. https:// doi.org/10.3390/su13105412

Academic Editors:

Oriol Pons-Valladares and

Jelena Nikolic

Received: 26 February 2021

Accepted: 7 May 2021

Published: 12 May 2021

Publisher's Note: MDPI stays neutral with regard to jurisdictional claims in published maps and institutional affiliations.

Keywords: sustainable; renovation; holistic approach; framework

\section{Introduction}

Sweden, like many other nations in Europe, faces a need for large-scale, urgent renovation of the post-war building stock that is past its technical, economic, and service life endpoint. Buildings are responsible for $40 \%$ of energy consumption and $36 \%$ of $\mathrm{CO}_{2}$ emissions in the EU, and it is predicted that $50 \%$ of the building stock that will exist in 2050 will have been built before 1975 [1]. Therefore, the renovation of existing buildings has the potential to lead to significant energy savings, potentially reducing the EU's total energy consumption by $5-6 \%$ and lowering $\mathrm{CO}_{2}$ emissions by approximately $5 \%$ [1]. This must be done without compromising environmental, social, and economic quality. The environmental sustainability category includes aspects of energy and environmental impact and use of resources; the social category includes aspects of indoor environment quality, architectural quality, functionality, quality of life, employment, and cultural historical aspects; and the economic category includes costs related to construction and operation. There is no general definition to describe building interventions, but a large variety of partly overlapping terms are in use, e.g., alteration, adaptation, renovation, rehabilitation, refurbishment, retrofitting, restoration, and reconstruction. In this paper the word renovation means a range from repairs with a minimum of interventions to major alterations of the original building, depending on the identified need.

In general, a renovation process includes more or less the same stages as the process of new construction (predesign, preliminary investigation and program formulation, design, construction, commissioning, and follow up during use phase). However, in 
renovation, more emphasis should be placed on the preliminary investigation in terms of the time and resources needed to achieve good results [2]. A schematic overview of a renovation process [3-5] can include: the needs of renovation caused by technical or functional obsolescence, inventories and documentation, early discussions with authorities, preinvestigation, designing alternative solutions, preliminary cost calculations, the decision to design, design, the discussion with users, the decision to construct, construction consent, alteration and renovation works, and the user phase and maintenance. During the renovation process, a number of decisions are made throughout the different stages, from the initial decisions on which buildings to renovate and to what extent, to the design of renovation measures to implement, to which methods of construction to use and how the renovation will be organized in terms of interaction with tenants, etc. There are also indications that uninformed architectural decisions lead to the replacement of existing, and often still functional, materials and building components with new ones that have shorter technical and aesthetic lifespans, resulting in increased material flows as well as the loss of architectural and historical value [6]. From this perspective, renovation involves a complex decision-making process in which multiple requirements and conditions must be taken into consideration simultaneously. Sustainable renovation, where environmental, social, and economic aspects are encompassed in a balanced way, therefore requires a multidisciplinary approach, involving experts from different fields of knowledge working alongside building owners, tenants, and practitioners to design, reconstruct, and operate buildings [3,7-9].

To understand the multidisciplinary and multiactor process, including how to make balanced decisions at each stage, it is necessary to obtain a sustainable renovation process. Working within the Sustainable Integrated Renovation (SIRen) research network [10] has been an opportunity for researchers and actors to meet, discuss, and elaborate upon the technical, environmental, economic, social, and cultural historical aspects of the renovation of buildings, as well as to identify and discuss new challenges. The SIRen research environment gathers researchers from engineering, architecture, social sciences, and real-estate management from a number of academic institutions and institutes in Sweden as well as committed industrial and public actors representing building owners, housing companies, facility managers, contractors, consultants, architects, building conservationists, authorities, and tenants' organizations. The SIRen research environment focuses on the complexities of the renovation of existing buildings. For example, the meaning of the words "sustainable renovation" was understood very differently by the different stakeholders when the research environment was established. The research environment's aim was thus to gather existing knowledge and build new knowledge in order to increase the understanding of sustainable renovation and to make renovation methods and processes more sustainable. This will strengthen Swedish competitiveness for renovation in terms of both practice and research and development, both nationally and internationally.

It was identified that there is a lack of practical methods and methodologies for sustainable renovation. In order to manage the complex issues arising during different stages in the renovation process, and to succeed with a sustainable renovation, the need both for an overarching, descriptive framework and process providing guidance throughout the renovation process and for references to supportive tools that can be used by different stakeholders at different stages was identified.

The aim of this paper is to present a transparent, openly accessible, adaptable framework for a sustainable renovation process, covering the technical, environmental, economic, social, and cultural historical aspects to be considered by the various actors during different stages. The intended use of the framework is the renovation of one or several buildings and the physical space between buildings. The research has focused on two questions:

- How could a framework for a sustainable renovation process be designed?

- What components in terms of stages, activities, and actors should be included?

The structure of the paper begins with a review of previous research in Section 2, and then the development and iterative improvement of the framework and process is 
described in Section 3. In Section 4, four renovation projects that were used as case studies in the iterative development process of the framework are described. The results shown in Section 5 include the outlines of the framework and the process together with associated descriptions of activities, links to tools and documents, and supporting documents, such as checklists for self-evaluation. In Section 6, the results are discussed in relation to earlier research, and conclusions are drawn.

\section{Previous Research}

Sustainable renovation generally refers to a renovation that fulfills the dimensions of environmental, social, and economic sustainability for the changes to buildings [5]. Several tools and frameworks for supporting sustainable renovation have been developed. Nielsen et al. reviewed and categorized 43 tools for early-stage decision support, which is perhaps the most common type of tool [7]. From here on, the concept framework is used to describe a set of tools covering more than just one stage in the renovation process. A pure decision support tool is not a framework in this sense, but many authors use the word framework even if it covers a more limited part of the building process. Some authors focus on the early decision-making stages for a project [5,8,9]. Thuvander et al. [5] made an inventory of different decision-making tools and processes that could fit within a framework using a literature survey and a workshop with stakeholders. Golic et al. [8] developed a framework which was based on the Swiss Sustainable Building Standard, with extra focus on social aspects. This framework covered the early stages of a project with emphasis on criteria and goal setting. Kamari et al. developed a multimethodology framework, also with emphasis on the early investigation and decision stages [9]. Kamari et al., on the other hand, developed a sustainability framework to audit, develop, and assess building renovation performance, and support decision making during the project's lifecycle [4]. A design framework was developed by Passoni addressing life cycle thinking and holistic perspectives in each phase of the design [11]. A framework was developed by Kamari et al. using empirical information to investigate the mapping of 18 criteria with 118 subcriteria to 139 renovation alternatives [12]. Blum and Grant presented a methodological framework and toolkit to support the decision-making process at different stages of a neighborhood development process using an aggregated index and directory of assessment tools for the built environment, based on credits awarded against a set of performance criteria [12]. As part of the RE-VALUE project [13], a metasynthesis of seven sustainability assessment methodologies was carried out, amongst others the Danish version of the German certification DGNB with indicators for economic, social, and environmental factors as well as for process sustainability [14].

For tools and frameworks that include decision support, the choice of criteria and quantified sustainability goals is, of course, critical. Zhang and Lai Lei suggested a framework for renovation of existing residential buildings based on environmental efficiency, which they defined as functional quality divided by environmental loading [15]. Environmental efficiency is derived from ecoefficiency, which is defined by the World Business Council for Sustainable Development (WBSCD) as the product or service value divided by its influence on the environment [16]. Ecoefficiency thus has much more focus on economic than environmental efficiency. The functional quality in [15] was calculated from functional ability, durability and reliability, flexibility and adaptability, and outdoor environment. For environmental loading, energy, resources and materials, and an off-site environment were used. Some authors, e.g., Kamari et al. [4] and Medinecke [17], used an existing set of sustainability criteria or certification systems, such as BREEAM [18], DGNB [14], and LEED [19]. However, many assemble their own set of criteria. Tupenaite used 8 criteria with 48 subcriteria [3], Jensen and Maslesa used 8 parameters with 34 subcriteria [20], and Kamari et al. used 18 criteria with 118 subcriteria [13]. There are different strategies for deciding on the criteria, e.g., having them chosen by the researchers in the scientific project [3], with focus groups of experts [8,15,21], by using stakeholder input [4,12,22], or with a mix of these strategies. Taillandier et al. developed a method for decision support re- 
garding the choice of renovation solutions that enables a merging of the project stakeholder points of view, based on a deep interaction between experts and owners [22]. Femenias et al. conducted a postreflective analysis of actor and stakeholder engagement to handle the decision-making process regarding the renovation of housing of cultural historical value [6].

To be able to quantify the sustainability goals or criteria, aggregated values of estimated or measured subcriteria must be implemented. Tupenaite et al. calculated an index representing the built and human environment from 48 subcriteria using simple additive weighting (SAW) [3], whereas Kamari et al. calculated three indexes: functionality (29 subcriteria), accountability (36 subcriteria), and feasibility (34 subcriteria) [4]. Malmqvist et al., on the other hand, used two indexes: external load index, including mostly energy aspects, and internal load index, based on a questionnaire about indoor environment [23]. Some authors use more standardized values, such as life cycle cost [24] or greenhouse gas (GHG) [25].

To display the results, simple diagrams [23] or rose diagrams with 4 axes [26], 7 axes [15], 8 axes [20], 14 axes [11], or 30 axes [4] can be used. Instead of diagrams or quantitative indexes, Taillandier et al. used the elimination and choice translating reality (ELECTRE) method to create a ranking [22].

The systems and methods for solving multiple criteria problems are called multiple criteria decision management tools (MCDM) and include strategies or mathematical algorithms for finding the "best" solution. If there are subcriteria with values (measured or estimated), weighting methods such as SAW (simple additive weighting), MEW (multiplicative exponential weighting), or COPAS (multiple criteria complex proportional evaluation) can be used [17]. The actual weighting factors can be set by qualitative estimation or a more systematic method such as analytic hierarchy process (AHP) [3,17].

Medineckie presented a tool that combined multicriteria decision-making (MCDM) methods and building certification systems in order to make weighted decisions in complicated construction tasks [17]. Jimenez et al. developed a multicriteria decision support method to select feasible and sustainable housing renovation strategies [27].

From the literature survey, it was clear that the questions about decision-making and performance methods have been studied at least since 1995 [7]. The field has a mature theoretical framing. The questions and problem formulations are "soft" in the sense that there is an acceptance that no well-defined optimal solution can be found; instead, the solutions to how a sustainable renovation method might be implemented is a matter of negotiation between the stakeholders in a given situation $[4,28]$.

\section{Materials and Methods}

\subsection{Development of Framework}

In order to answer the two research questions, a starting point for developing a renovation framework was needed. This starting point was chosen to be a framework inspired by the successful example ByggaF for assuring moisture safety in the building process [29]. ByggaF consists of a set of systematic activities, checklists, documents, and guidelines for all stages in a construction project. In a similar way, a renovation framework with an associated process was drawn up. This framework did not focus heavily on the theoretical methodologies and nomenclature but rather on the practical usefulness, together with the fundamental idea that sustainability cannot be a sub requirement but has to be the overall requirement present in all stages of the process. The reason a new framework was developed, as opposed to using an existing one, was that practitioners in the SIRen project were reluctant to use methods with too much theoretical overhead. The new framework was called the SIRen framework (Sustainable Integrated Renovation framework), and each activity was linked to existing methods and tools openly accessible on the market or web (in Sweden). In this way, the framework can be adopted using the same general activities, but linking different methods and tools for different countries and regions and adapting to 
national constraints, such as building regulations, rent regulations, financial and market constraints, ownership, subsidies, energy targets, climatic conditions, etc.

The purpose of the framework is to provide a holistic view of sustainable renovation and to guide the building owner and other stakeholders involved through all stages of the renovation process, introducing important activities that must be carried out to achieve a sustainable renovation process and a sustainable renovated building. Methods that can be used for inventories, analyses, the evaluation of alternative renovation measures, and guiding decision making are referenced. The framework suggests different tools and methods to be used by stakeholders during all stages of the renovation process. The framework has both an informative part and an evaluative part. Throughout, all activities and methods must contribute to a long-term and/or life cycle perspective. Depending on the particular aspect that is analyzed, a long-term or life cycle perspective is most suitable. For example, the aspects of indoor environment and cultural values are best analyzed using a long-term perspective, whereas the environmental impact of components and structures, e.g., relining vs. changing pipes and upgrading vs. installing new kitchens, is best analyzed using a life cycle perspective. The SIRen framework emphasizes the importance of a holistic perspective and includes the following areas: technology, environment, economy, social values, architectural and cultural environment, functionality, and the renovation process inspired by the German system DGNB [14]. This particular choice of system was partly made due to its emphasis on social and cultural aspects, which was something that was deemed important by the stakeholders involved in the SIRen research environment (see Figure 1).

\begin{tabular}{ll}
\hline Socio cultural and functional & -Indoor environment \\
\hline & -User participation and dialogue \\
\hline & -Outdoor environment \\
\hline & -Accessibility \\
\hline Environmental & -Architecture and cultural historical values \\
\hline & -Energy \\
\hline & -Resources \\
\hline Technical & -Hazardous chemicals \\
\hline & -Building services \\
\hline Economic & -Durability and Moisture \\
\hline Process & -Life cycle cost \\
\hline
\end{tabular}

Figure 1. Sustainability aspects taken into consideration in the SIRen process.

\subsection{Improvement of Framework through Interaction with Stakeholders}

During a number of workshops arranged from 2014 to 2018 within a network of researchers and stakeholders from the Swedish renovation sector, the structure of the framework was drawn up and gradually improved: more activities were added, the different process chains were described in more detail, and more examples of already existing tools for inventory and decision support were added. The leading principle for the workshops was to find practical methods and agreeable values for sustainable renovation. In 2017, parts of the framework were tested in active renovation projects [30,31]. In 2018, a checklist was added for self-evaluation of sustainability, partly inspired by the Swedish Agency for Economic and Regional Growth's Sustainable Business [32].

Information and links to existing tools were gradually identified and replenished. Division into stages and actors' groups was developed in consultation with the participants of the SIRen researchers and practitioners network. Actors linked to the research network 
were asked to use the process in active renovation projects. As feedback was received from the users, improvements to the process structure and content were made.

\section{Case Studies Used in the Iterative Development Process}

Four renovation projects shown in Figure 2 were used as case studies in the iterative development process of the framework. The outline of the process was introduced and followed up by one or two researchers and practitioners in the SIRen network, and results and experience were reported back to the network at meetings and used for improving the framework.

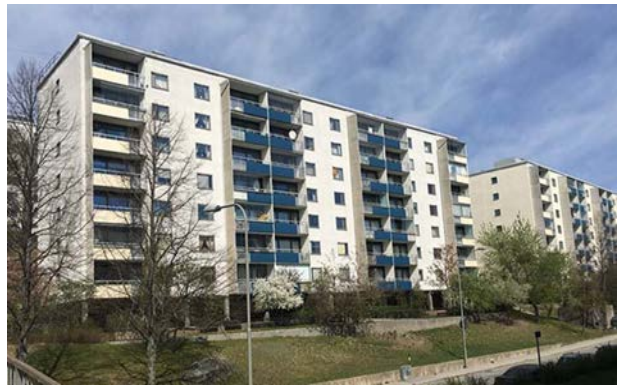

(a)

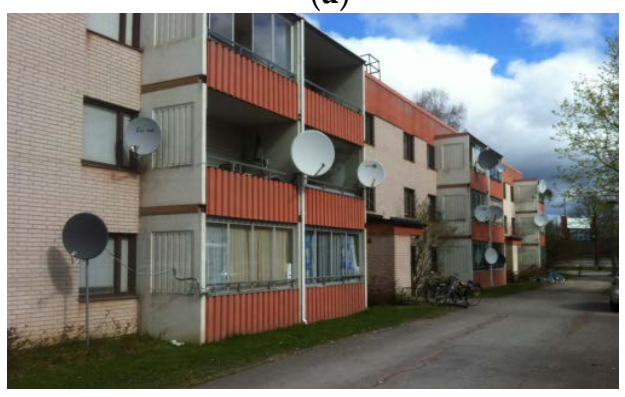

(c)

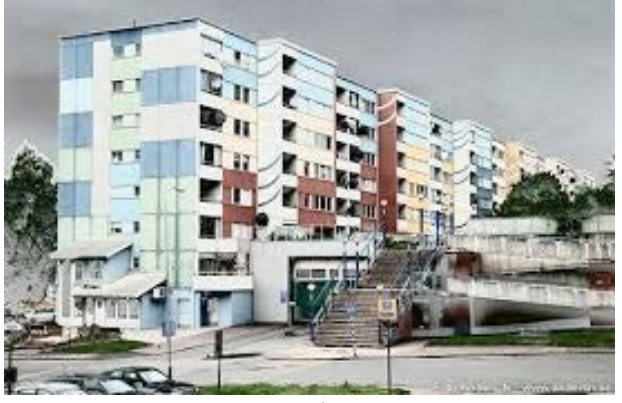

(b)

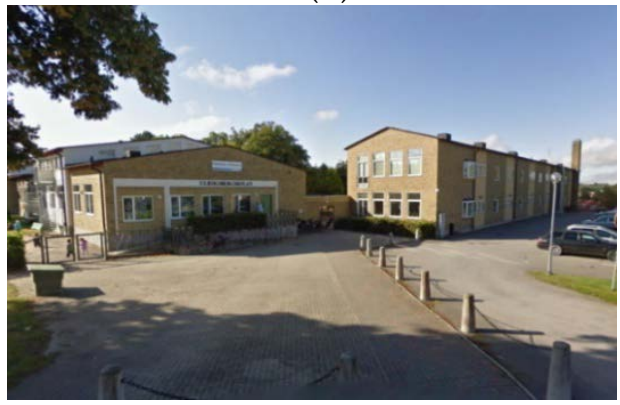

(d)

Figure 2. The four case studies: (a) Skärholmen, Stockholm; (b) Siriusgatan, Gothenburg; (c) Tjärna Ängar, Borlänge; (d) The Ulriksberg School, Växjö.

\subsection{Residental Housing Area in the West of Sweden}

The residential area Siriusgatan is one of many areas built in the 1960s in urgent need of renovation. Technical deficiencies, such as leaking facades, and high costs for operation and maintenance were identified, which led to the planning of an extensive renovation project, including both reconstruction and renovation of apartments and energy efficiency measures. The renovation would involve high costs for investments as well as increased rent levels, which caused the management group to halt and restart the process [33].

During the late spring of 2015, a housing company contacted researchers within the SIRen research network to request advice on how to plan and execute a sustainable renovation, in terms of social, environmental, and economic sustainability. The housing company expressed that they mostly focused on new construction, but that maintenance and renovation had to be delayed despite major challenges in several existing areas with neglected maintenance and major renovation needs. The housing company also wanted to increase the attractiveness of these areas with existing housing. After some initial meetings, the researchers suggested that they should follow the SIRen process for a strategic holistic approach with the aim of achieving a more sustainable renovation as described above. As a result, careful work on an action program was initiated, where support was provided by researchers in the SIRen network. Several action packages were studied based on the opportunities and risks. Taking into account the residents' minimal ability to afford an increase in rent and the city's goal that no one should have to move apartments as a result of a rent increase caused by renovation, the management group decided to proceed with a 
renovation with limited interventions, including measures on facade and in the outdoor environment. Interior renovations are still needed but are planned to be implemented at a later stage. The planned gentle renovation will be implemented stepwise and at multiple stages. The measures involve some new facades and windows, additional insulation of some facades and roofing, decontamination of PCB in facade joints, installation of PVs on roofs, new drainage, and the rehabilitation of waste rooms, laundry rooms, and the outdoor environment. There will also be energy efficiency measures leading to a $20-25 \%$ energy savings, and the buildings will be prepared for future installation of a supply and exhaust ventilation system with heat exchangers. The renovation that is now planned will lead to a low rent increase.

The renovation of Siriusgatan illustrates the conflicting objectives where political targets in terms of energy savings and development goals for the suburbs are difficult to fulfil in tandem with social consideration for residents, given the municipality goals that no one should have to relocate as a result of renovation. By working according to the SIRen process and taking into consideration economic, social, and environmental aspects, these conflicts were raised early in the process, which means that more informed decisions could be made [33].

\subsection{Residental Housing Area in the Middle of Sweden}

The residential area Tjärna Ängar, consisting of 36 residential buildings constructed in 1970s and owned by the public housing company Tunabyggen AB, is undergoing extensive renovation. Initially the company worked according to an established construction process, but the approach was gradually developed with new findings from research, industry, and authorities. In this specific case, Tunabyggen applied a method for careful renovation proposed by the researchers, which is well in line with the SIRen framework. The ambition was to implement and establish sustainable renovation with caution, e.g., with solutions that involve reasonable costs, which means that a close to zero energy solution also fulfils the owners' requirements of return on investments, and solutions that allow for residents to remain in their apartments during renovation with minimal disturbance to avoid costly and impractical evacuation. In addition, there was a focus on choosing robust techniques, but also on improving the thermal comfort in the apartments in connection with energy efficiency measures. Decisions and processes also had to be in line with the ability and competence of the actors involved in the project, which also required that information be available at the right time to facilitate for strategic actors to impact decisions as well as the quality of work. Tunabyggen engaged researchers from Dalarna University to support them in developing packages of renovation measures as well as in following up on the renovation process. The focus for the researchers has been on presenting sustainable solutions with the intention to identify and demonstrate sustainable solutions to proceed with in the entire building stock. The project started off with a workshop gathering the building owner and all consultants and contractors to discuss common goals and ambitions, resulting in a target document. At the early stage, a number of investigations, such as an energy survey and energy measurements, were done to obtain information on the status of the building before renovation, and these were repeated after renovation for assessing the effect of the performed actions. Qualitative interviews with residents in 10 apartments in the first pilot building were conducted two times, before and after renovation. The specific issues that were brought up in the interviews with tenants were formulated by researchers from social and behavioral science in consultation with researchers from technical science, mainly considering indoor comfort but also disturbance during the ongoing renovation. The interview study was complemented with interviews in the other two buildings as the project progressed.

In Tjärna Ängar, three pilot buildings were renovated with different systems in order to evaluate which system to proceed with. The first renovated building has 36 apartments in three floors, an exhaust ventilation system, and a single-pipe heating system connected to a district heating system. Renovation measures included additional insulation, new 
windows, and the installation of a heat exchanger on the exhaust ventilation using heat pump and supply air radiators, which could be installed without the evacuation of tenants. In the next building, only renovation measures at the building envelope, including additional insulation and new windows, were made. The third building had a traditional heat exchange system on exhaust ventilation installed, which required the evacuation of tenants.

Conclusions from the project were that it has been possible to implement sustainable renovation in the residential area of Tjärna Ängar. The monitoring of the three pilot projects will go on for one more heating season in order to evaluate the effect of different renovation packages. The interviews done after the renovation proved that the preheating of incoming air at the radiators has eliminated the problems with draft at the windows and improved thermal comfort in general. The owner estimates a $40 \%$ reduction in time for evacuation compared to the traditional heat exchange solution and, in total, a reduction of 15 weeks construction time for renovation. If no interior measures are completed, evacuation is not needed at all. Reduced return temperature results in higher efficiency in the district heating system, which contributes to a higher efficiency in the system on a city scale, which could have consequences on tariffs. The LCA analysis of renovation packages proved that the global warming potential decreased after the renovation for all pilot buildings, with a payback time between 13 and 32 years, depending on which renovation package was completed [24].

\subsection{Residental Housing Area in the East of Sweden}

The public housing company Stockholmshem, with a multifamily housing stock of 27,500 apartments, is part of the SIRen research network. They implemented the first part of the SIRen process in the renovation of an area of 700 apartments in Skärholmen as a case study. Together with an architectural firm and a consultant with expertise in gentle interior renovation, they started off the work by organizing a workshop on sustainable renovation with the site manager, project manager, business developer, project communicator, and tenant/customer relations officer. According to practice, technical inventories, such as fire safety, electricity, acoustics, environment, status of roof and laundry rooms, and heating and ventilation, were performed prior to renovation, which resulted in a list of suggested measures. In addition, a number of investigations were planned considering moisture safety, elevators, structures, cultural historical values, and accessibility. However, there were no investigations planned for tenants' experience and architectural qualities of the apartments and the local environment. During the workshop, a local area analysis was presented. In addition, the consultants suggested methods for energy efficiency, renewable energy production, and interior renovation analysis, including inventory and identification of architectural qualities. Conclusions from the workshop were that gentle renovation which included the development of existing qualities, accessibility, long-term profitability, and energy efficiency, in combination with the possibility to produce renewable energy on site, was important.

The installation of photovoltaics for the production of renewable energy on the roof was planned and designed for. An expert was consulted for the choice of location of the PVs and to foresee both the technical and aesthetic interests, considering both existing installations and the view from buildings nearby and from the ground.

According to the SIRen process, both existing architectural and cultural historical values should be investigated before renovation. As a result, interior inventories were made in all apartments with the aim to preserve and refurbish as much of the interior as possible instead of tearing it out. The results of the inventories showed that solid interior structures such as cabinets in the kitchen, bathroom, and entrance were in good condition, so the recommendation was to refurbish them rather than to tear them out and insert new kitchens and bathrooms, in combination with changing drain pipes. A major part of the kitchen cabinet doors could be repainted and upgraded with new knobs.

The results from both the technical, architectural, and cultural historical interior investigations served as a basis for decisions on renovation measures. The extended 
inventories and analyses gave better conditions for the procurement of the right competence as well as for making decisions on sustainable renovation. In the case of Stockholmshem, the focus clearly changed during the time of the project with an increased interest to preserve and refurbish as much of the interior as possible, instead of tearing out and inserting new kitchens and bathrooms, which was the initial plan. The result was a gentle but more sustainable renovation [34].

\subsection{School Building in the South of Sweden}

The municipal school and preschool in Växjö, with 350 pupils ranging in age from 1 to 5 and 6 to 12 years, respectively, are in need of total reconstruction due to poor indoor and outdoor environments, but also due to high costs for maintenance. Moreover, accessibility requirements are not fulfilled, and the premises are not appropriate for today's educational activities. The options discussed were: retain existing buildings and carry out necessary maintenance; conduct less extensive renovations of a few buildings; conduct extensive renovation of the entire school; demolish and reconstruct some buildings; and demolish all buildings and build a new school.

During the renovation process, the SIRen framework was used to take a holistic approach and highlight more sustainability aspects for discussion at an early stage. Two researchers introduced the SIRen framework to the project group consisting of representatives from the building owner and the municipality, guided them through the different stages, and presented the available tools. The researchers participated in nine project meetings and followed up the decision process with the purpose to evaluate how decisions are taken in early stages up to the design brief. The methods used were document analysis and participation in and documentation of discussions at meetings.

The main discussion was considering targets for renovation with the purpose of presenting different renovation alternatives. It was noted that aspects such as technical status, energy use, and indoor environment were not discussed to a large extent from the start. The discussions mainly handled accessibility, functionality in terms of a stimulating the teaching and learning environment, the flexibility of the premises for adopting new teaching and learning methods, the efficient use of space for covering the municipality's need for places for education, and safety aspects (for example, traffic generated when parents pick up and drop off their children at school). A few inventories were carried out for determining technical status and accessibility. These were complemented by investigations on energy use, indoor environment, and cultural historical values, which did, among other things, lead to the decision to preserve a building that was intended to be demolished in the first stage. Financial aspects were discussed to a very limited extent, even though a political decision is required for investments. The users of the buildings were not involved due to a change in personnel until the first renovation plan was presented, which led to a reactive, rather than proactive, dialogue process, which is a lesson to carry over to the next project and must be stressed when implementing the SIRen process. Another important group of people that should be involved early in the process are the politicians, who will be the ones making the final decision on investments in order to complete the renovation. This study illustrates that a comprehensive analysis is needed when renovating a building and brings up the difficulties of addressing and evaluating all the viable aspects of concern as well as the importance of involving the stakeholders concerned as early as possible. It shows that the planning of a renovation is not a straight line but rather a process where conditions continuously change. The conclusion is that using the holistic SIRen framework and working according to the suggested SIRen process assured that technical, environmental, social, economic, and cultural historical aspects were considered and supported the project group in taking the necessary actions and making the necessary decisions at early stages $[30,33]$. 


\section{Results}

\subsection{Overall Structure of the Framework}

The framework is divided into four steps: overview, description of activities, links to external tools and documents, and finally a checklist to be completed after each process stage. The results from the checklist are reported as rose diagrams. Depending on the stakeholder who will use the framework, there are different examples and suggestions for activities and tools at all process stages. The framework can be used by property owners, architects, consultants, contractors, suppliers, operation and management teams, representatives for the users, authorities, etc. The framework is implemented in an Excel sheet supported by a written manual. The idea is that the framework can be used not only during the actual project work but also when individual process stages are completed and are to be evaluated.

\subsection{Overall Structure of the Process}

The suggested process in the SIRen framework starts out from the operation and management stage, since this is where the foundation for sustainable integrated management, maintenance, and renovation of buildings is formed. With deep knowledge about the technical status of the buildings stock as well as knowledge of the degree of satisfaction and wellbeing of the occupants of the buildings, it is possible to have a long-term strategy for well-planned maintenance and renovation without any emergency actions, which often involve high costs and inconvenience for the users. The denomination of the various process stages has been worked out during the workshops with researchers and practitioners in the SIRen network (see Figure 3). The vocabulary is necessarily a compromise because different companies and organizations use partly different terms.

\begin{tabular}{|l|l|l|l|l|l|l|l|l|l|}
\hline & \multirow{2}{*}{$\begin{array}{l}\text { Operation } \\
\text { and man- } \\
\text { agement } \\
\text { stage }\end{array}$} & $\begin{array}{l}\text { Planning stage } \\
\text { Pre- } \\
\text { study }\end{array}$ & $\begin{array}{l}\text { Investi- } \\
\text { gation }\end{array}$ & $\begin{array}{l}\text { Pro- } \\
\text { gram }\end{array}$ & $\begin{array}{l}\text { System } \\
\text { design }\end{array}$ & $\begin{array}{l}\text { De- } \\
\text { tailed } \\
\text { design }\end{array}$ & $\begin{array}{l}\text { Reconstruc- } \\
\text { tion stage }\end{array}$ & $\begin{array}{l}\text { Commis- } \\
\text { sioning } \\
\text { stage }\end{array}$ & $\begin{array}{l}\text { Follow- } \\
\text { up } \\
\text { stage }\end{array}$ \\
\hline $\begin{array}{l}\text { Building } \\
\text { owner }\end{array}$ & & & & & & & & & \\
\hline User & & & & & & & & & \\
\hline Expert & & & & & & & & & \\
\hline $\begin{array}{l}\text { Contrac- } \\
\text { tor }\end{array}$ & & & & & & & & & \\
\hline Supplier & & & & & & & & & \\
\hline Manager & & & & & & & & & \\
\hline
\end{tabular}

Figure 3. Stages and actors used in the process in the SIRen framework.

Table 1 shows activities that are to be carried out at the first four stages of the process and map who is responsible for and carries out these activities. Table 2 shows the same for the last five stages. 
Table 1. Activities that are to be carried out at the first 4 stages according to the SIRen process.

\begin{tabular}{|c|c|c|c|c|}
\hline Actor & $\begin{array}{l}\text { Operation and } \\
\text { Management }\end{array}$ & Feasibility Study & Investigation & Program \\
\hline Owner & $\begin{array}{l}\text { Develop strategy for } \\
\text { maintenance and a } \\
\text { vision for renovation } \\
\text { with a focus on } \\
\text { sustainability. Mapping } \\
\text { status stocks. Develop } \\
\text { a policy for user dia- } \\
\text { logue/communication } \\
\text { with residents. }\end{array}$ & $\begin{array}{l}\text { Define the framework } \\
\text { for the project. Ensure } \\
\text { that an inventory is } \\
\text { made of energy, } \\
\text { moisture, construction, } \\
\text { user needs, indoor } \\
\text { environment, security, } \\
\text { accessibility, } \\
\text { cultural-historical } \\
\text { values, and technical } \\
\text { status. }\end{array}$ & $\begin{array}{l}\text { Ensure that necessary } \\
\text { investigations are done, } \\
\text { especially with a focus } \\
\text { on sustainability. } \\
\text { Involve residents. }\end{array}$ & $\begin{array}{l}\text { Choose program } \\
\text { options and vision. Use } \\
\text { of tools to compare the } \\
\text { sustainability of } \\
\text { different options. }\end{array}$ \\
\hline User/Resident & $\begin{array}{l}\text { Participate in the } \\
\text { dialogue with the } \\
\text { property owner. }\end{array}$ & $\begin{array}{l}\text { Participate in the } \\
\text { dialogue with the } \\
\text { property owner. }\end{array}$ & $\begin{array}{l}\text { Participate in dialogue } \\
\text { with the property } \\
\text { owner (e.g., about rent } \\
\text { increase alternatives). }\end{array}$ & $\begin{array}{l}\text { Participate in the } \\
\text { dialogue with the } \\
\text { property owner. }\end{array}$ \\
\hline Expert & & $\begin{array}{l}\text { Perform inventory of } \\
\text { architecture, user needs, } \\
\text { indoor environment, } \\
\text { security, accessibility, } \\
\text { cultural values, energy, } \\
\text { moisture, construction, } \\
\text { plumbing, indoor } \\
\text { environment (thermal } \\
\text { comfort, acoustics, air } \\
\text { quality), technical } \\
\text { status of materials and } \\
\text { components. }\end{array}$ & $\begin{array}{l}\text { Perform investigations } \\
\text { based on the inventory. }\end{array}$ & $\begin{array}{l}\text { Assist with analysis } \\
\text { and documentation for } \\
\text { various alternatives } \\
\text { based on the } \\
\text { investigation. }\end{array}$ \\
\hline Contractor & & & $\begin{array}{l}\text { Assist with cost } \\
\text { estimates. }\end{array}$ & $\begin{array}{l}\text { Assist with cost } \\
\text { estimates. }\end{array}$ \\
\hline Supplier & & & $\begin{array}{c}\text { Assist with cost } \\
\text { estimates. }\end{array}$ & $\begin{array}{c}\text { Assist with cost } \\
\text { estimates. }\end{array}$ \\
\hline Managers & $\begin{array}{l}\text { Ongoing management } \\
\text { and maintenance. } \\
\text { Follow up of operation. } \\
\text { Information to owners. } \\
\text { Ongoing } \\
\text { communication with } \\
\text { users/tenants. Deal } \\
\text { with minor } \\
\text { deviations/damages. }\end{array}$ & $\begin{array}{l}\text { Contribute } \\
\text { documentation to the } \\
\text { inventory. }\end{array}$ & $\begin{array}{l}\text { Contribute } \\
\text { documentation to the } \\
\text { investigation. }\end{array}$ & $\begin{array}{l}\text { Contribute } \\
\text { documentation to the } \\
\text { investigation. }\end{array}$ \\
\hline
\end{tabular}


Table 2. Activities that are to be carried out at the last 5 stages according to the SIRen process.

\begin{tabular}{|c|c|c|c|c|c|}
\hline Actor & System Design & Detailed Design & Reconstruction & Commissioning & Follow Up \\
\hline Owner & $\begin{array}{l}\text { Ensure that } \\
\text { construction } \\
\text { documents are } \\
\text { produced. Ensure } \\
\text { that requirements } \\
\text { for sustainability } \\
\text { are included in the } \\
\text { procurement of the } \\
\text { design. Choose } \\
\text { strategies for } \\
\text { remaining or }\end{array}$ & $\begin{array}{l}\text { Ensure that } \\
\text { requirements for } \\
\text { sustainability are } \\
\text { included in the } \\
\text { procurement of an } \\
\text { entrepreneur. }\end{array}$ & $\begin{array}{l}\text { Training/info for } \\
\text { all employees of } \\
\text { the project's goals } \\
\text { and how these } \\
\text { should be followed } \\
\text { up. Information } \\
\text { meetings for users, } \\
\text { especially with a } \\
\text { focus on } \\
\text { sustainability } \\
\text { goals. }\end{array}$ & $\begin{array}{l}\text { Ensure that } \\
\text { manager and users } \\
\text { are trained in the } \\
\text { function of the } \\
\text { house, especially } \\
\text { with a focus on } \\
\text { sustainability } \\
\text { aspects. }\end{array}$ & $\begin{array}{l}\text { Evaluation of } \\
\text { process and results. } \\
\text { Ensure that energy } \\
\text { declaration is } \\
\text { produced. Submit } \\
\text { energy verification } \\
\text { of the building } \\
\text { permit. Feedback } \\
\text { to own } \\
\text { management. }\end{array}$ \\
\hline User/Resident & $\begin{array}{l}\text { Participate in the } \\
\text { dialogue with the } \\
\text { property owner }\end{array}$ & & & $\begin{array}{l}\text { Participate/take } \\
\text { part in training. }\end{array}$ & $\begin{array}{l}\text { Respond to user } \\
\text { surveys and } \\
\text { present comments. }\end{array}$ \\
\hline Expert & $\begin{array}{c}\text { Develop } \\
\text { construction } \\
\text { documents. Protect } \\
\text { architectural and } \\
\text { cultural values. }\end{array}$ & $\begin{array}{c}\text { Follow up on } \\
\text { detailed design. }\end{array}$ & $\begin{array}{l}\text { Follow up on the } \\
\text { requirements, e.g., } \\
\text { energy, fire, } \\
\text { accessibility, } \\
\text { moisture safety, } \\
\text { etc. }\end{array}$ & & \\
\hline $\begin{array}{l}\text { Contractor } \\
\text { Supplier }\end{array}$ & & & $\begin{array}{l}\text { Ongoing } \\
\text { information to and } \\
\text { contact with users. } \\
\text { Handle special } \\
\text { conditions, e.g., } \\
\text { remaining tenants. } \\
\text { Minimize and sort } \\
\text { waste in a } \\
\text { sustainable way. } \\
\text { Quality control. }\end{array}$ & $\begin{array}{c}\text { Education } \\
\text { manager. Heat and } \\
\text { ventilation system } \\
\text { adjustment. }\end{array}$ & \\
\hline Manager & & & $\begin{array}{c}\text { Ongoing } \\
\text { information and } \\
\text { contact with users. }\end{array}$ & Become educated. & $\begin{array}{l}\text { Measurement of } \\
\text { operation/energy. } \\
\text { Survey of social } \\
\text { status and indoor } \\
\text { environment. }\end{array}$ \\
\hline
\end{tabular}

\subsection{Links to Tools, Routines and Documents}

To support the actors locating useful tools, the framework provides references to existing tools, routines, and templates (national and international): for example, methods that can be used for inventories, certification, and decision support. In this way, the actors can access help with tools and documentation that are suitable during each process stage. Examples of tools and documentation include:

- Routines for user dialogue during the renovation process [8];

- Tools for multicriteria sustainability analysis (ReBo [35], RenoBuild [36]);

- Tools for certification (BREEAM [18], DGNB [14], LEED [19]);

- Tools for social and cultural inventory;

- Documents such as building code and best practices.

For obvious reasons, many of the tools and documents are specific for the country where the framework is used-in this case, Sweden. As shown above, however, there are also many international references. 


\subsection{Check List and Self Evaluation}

The framework also provides a template for self-evaluation (a checklist) that can be used after each stage to evaluate what relevant aspects of sustainability have been taken into consideration and to what extent.

When a stage in the SIRen process is completed, this stage can be evaluated by answering the relevant part in a checklist consisting of a total of about a hundred statements for which the users rate their contribution from a sustainability point of view. The rating $(R)$ is on a scale of $0-3$, where 0 means "not implemented" and 3 means "detailed implementation". Each statement is associated with a weight that is distributed on all the sustainability aspects in Figure 1. See Figure 4 for two examples of statements and weights.

\begin{tabular}{|c|c|c|c|c|c|c|c|c|c|c|c|c|}
\hline & $R$ & $\begin{array}{l}\text { Ind. en- } \\
\text { vir. }\end{array}$ & $\begin{array}{l}\text { User part. } \\
\text { and dia. }\end{array}$ & $\begin{array}{l}\text { Outd. } \\
\text { envir. }\end{array}$ & Acc. & $\begin{array}{l}\text { Arch. and cult. } \\
\text { hist. val. }\end{array}$ & Ener. & Res. & Haz. chem. & Build. serv. & $\begin{array}{c}\text { Dur. and } \\
\text { Moist. }\end{array}$ & LCC Ren. process \\
\hline $\begin{array}{l}\text { Mapping of the } \\
\text { technical and ar- } \\
\text { chitectural status } \\
\text { of the stock. }\end{array}$ & $R$ & 1 & & 1 & 1 & 1 & & 1 & 1 & 1 & 1 & 1 \\
\hline $\begin{array}{l}\text { Develop a policy } \\
\text { for user dialogue }\end{array}$ & & & & & & & & & & & & \\
\hline $\begin{array}{l}\text { / communication } \\
\text { with residents } \\
\text { and users. }\end{array}$ & $R$ & & 1 & & & & & & & & & \\
\hline
\end{tabular}

Figure 4. Two examples of statements that are self-evaluated by a number $R$ between 0 and 3 . Weighting factors for each sustainability aspect is also shown.

The entire checklist is presented in Appendix A. All aspects are grouped under a certain stage, and a rose diagram is made to visualize the sustainability that has been achieved. The rose diagram's axes are based on the grouping of sustainability aspects according to Figure 1. Figure 5 shows examples of the results from the first six stages.

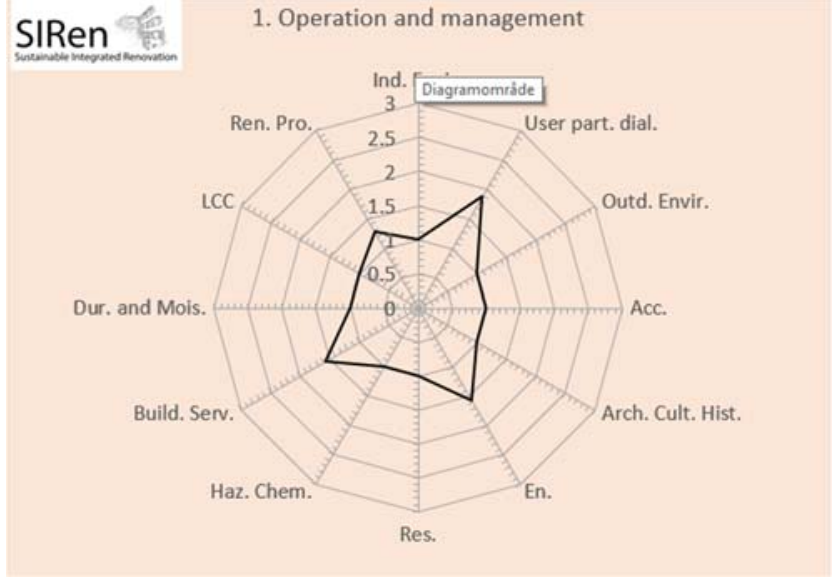

(a)

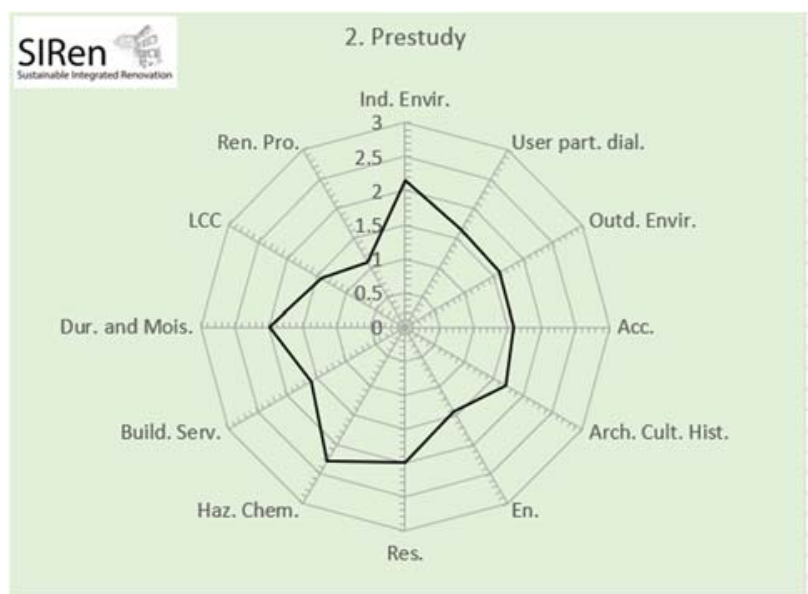

(b)

Figure 5. Cont. 


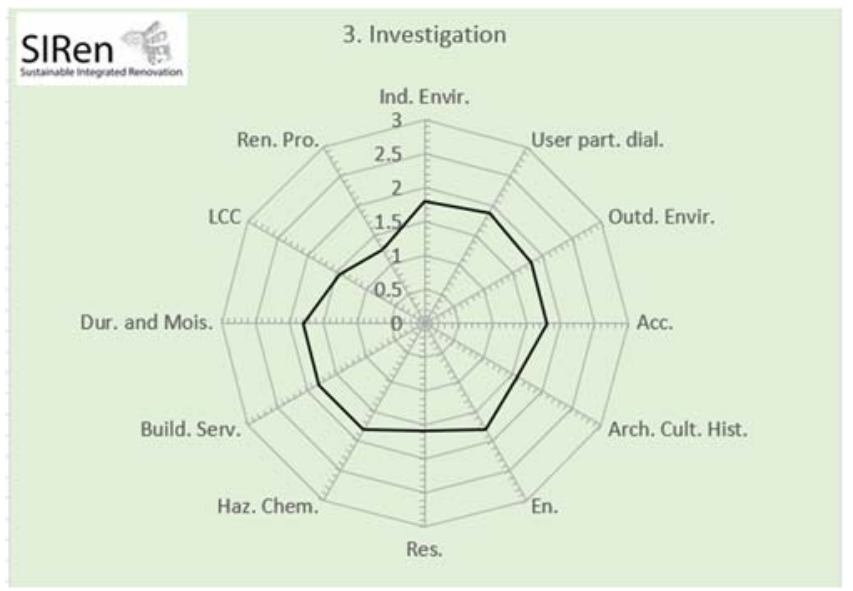

(c)

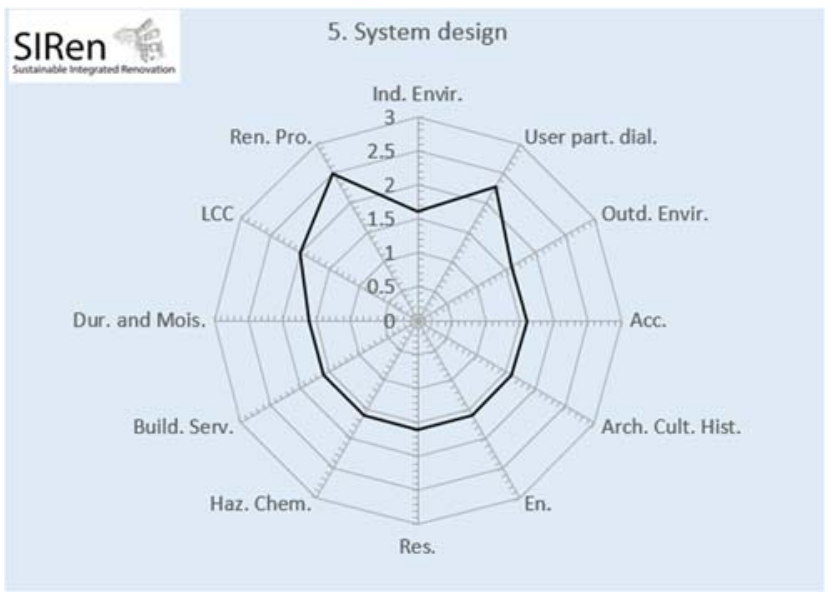

(e)

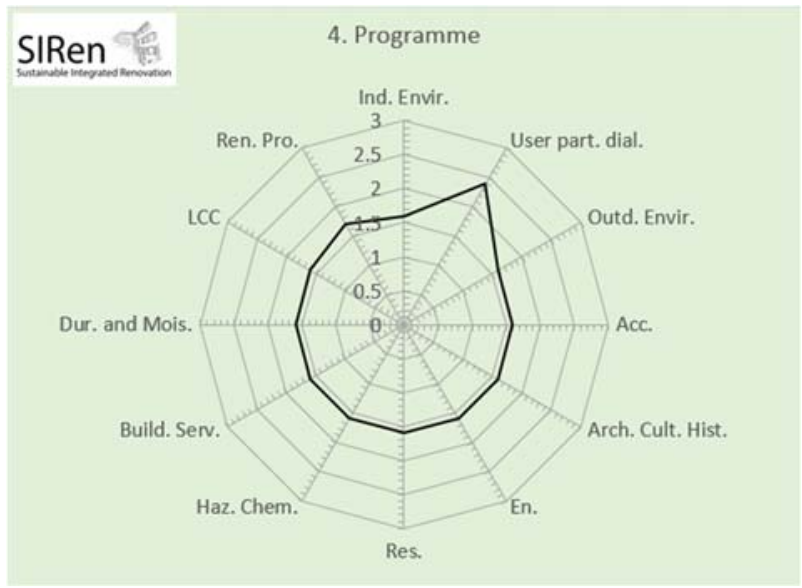

(d)

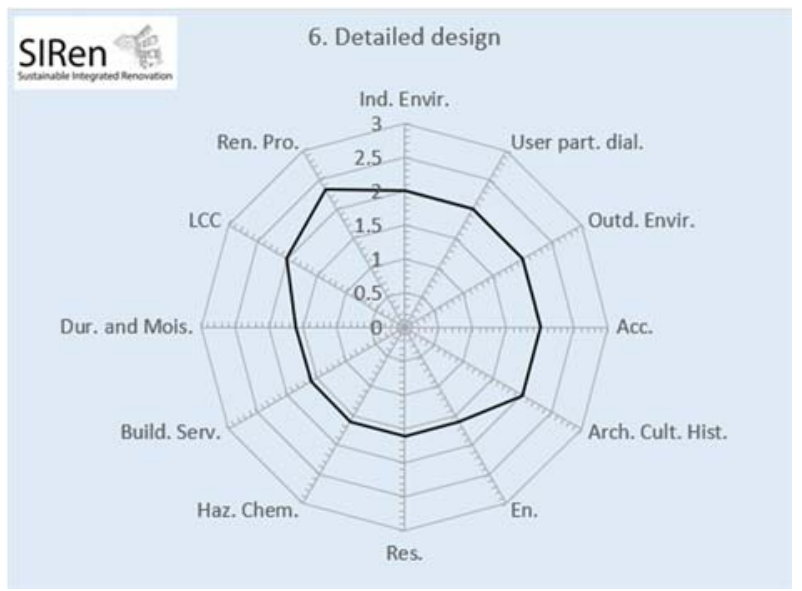

(f)

Figure 5. Example of results from self-evaluation of the first 6 stages shown in Figure 3: (a) Operation and management; (b) Prestudy; (c) Investigation; (d) Programme; (e) System design; (f) Detailed design.

The current version of the SIRen framework is not a certification or standardization method, but rather a methodology guiding building owners and other stakeholders to carry out sustainable renovations with a holistic view. The long-term goal is that the models, methods, and tools for integrated sustainable renovation that have been developed will be used widely and on a large scale in the renovation sector in the future.

\section{Discussion and Conclusions}

The aim of this paper is to present a transparent, openly accessible, adaptable framework for a sustainable renovation process covering technical environmental, economic, social, and cultural historical aspects that must be considered by the various actors during different stages of the renovation process. It has been noted many times that there is a need for practical methods to complement the strong focus on economy in decision processes aiming at sustainable solutions $[3,5,6,8,24,30,37]$.

The first research question was: how could a framework for a sustainable renovation process be designed? By starting with the advantages of existing tools for renovation (project management tools, status inventories, and multicriteria evaluation tools) as well as the experiences and feedback from previous projects, a framework and an associated ninestage process for sustainable integrated renovation was developed. The framework was built to include activities, methods, and tools applicable throughout the entire renovation 
process. The structure and criteria for the sustainability analysis were based on the German Sustainability Building Council system (DGNB) [14]. From the literature survey it was clear that many different methods have been suggested for sustainability analysis $[3,4,12,13,17]$, among them DGNB [14]. This particular structure was chosen due to its emphasis on social and cultural aspects, which were deemed important in the SIRen project. The framework and process were developed to satisfy the identified need from practitioners in the SIRen project for simple and straightforward methods and tools for renovation.

These type of "meta" frameworks have been suggested before $[5,8,9,11,12,17]$, but often with a specific numerical MCDM method, resulting in one or more aggregated numbers $[3,13,20,27]$ or a ranking $[3,22]$. A numerical value can point to a specific renovation choice but will always be dependent upon the numerical weighting factors in a more or less hidden way [17]. Previously developed "meta" frameworks have not been frequently used in practice [5], probably because of the perceived complexity of such frameworks. The SIRen framework proposes a process for sustainable renovation referring to existing tools, routines, and reference works that should be used by different actors in different stages of the renovation process. The advantage is that it is possible to adopt the framework to other countries' conditions in terms of legislation, building traditions, structure of the renovation sector, ownership, and relations to tenants.

The second research question was: what components in terms of stages, activities, and actors should be included? The SIRen framework is very much based on the same stages as a traditional construction project, with emphasis on the early planning stages, including prestudies, investigation, and program formulation. The most prominent difference, however, is that it starts with the operation and management stage. The reason is that this is the most important stage where all information is obtained and preparations are made for forthcoming renovations. If the owner and manager of the building or buildings are well aware of the technical status of building components, installations, and user satisfaction and needs, all necessary interventions can be planned well in advance, in terms of investments, relocation of tenants, etc., and no emergency actions are needed. Based on the information obtained during the operation and management of the building or buildings, all necessary data on, for example, energy performance, remaining lifetime of components, complaints by users, arising problems or damages, decisions on prestudies, and further investigations can be obtained. The result from these steps provides the basis for the focus and extent of the renovation program formulated in the program stage. The planning stage mainly involves experts or consultants conducting the different prestudies and investigations, whereas the owner and architect are involved in the program stage. The next step involves system design and then detailed design. At this point, it is possible to evaluate different renovation alternatives from the perspective of different sustainability aspects in order to identify the optimal solution and support the decision of what reconstruction or renovation actions are to be performed. The next stage is to perform the reconstruction or renovation work, followed by the commissioning stage and finally the follow up during operation and use of the renovated building(s).

When presenting the SIRen framework and the checklist with self-evaluation to people in the building industry, it became obvious that there was a pedagogical problem in not specifying a certain requirement level or grading system.

Many certification systems and sustainability tools focus on and analyze how sustainable the object, i.e., a building, is. This is done in different ways described above, e.g., by calculating energy demand, land, and water usage [12]. Contrary to many proposed MCDM models $[3,9,15,22,26]$, the SIRen process focuses on the renovation process itself, and the self-evaluation gives numerical values in the form of rose diagrams, representing to what extent the actors have considered and implemented the different aspects of sustainability in the different stages of the renovation process. The SIRen framework highlights all important steps to be taken and helps to keep track of these steps. Currently, this idea of focusing on a sustainable process is not proven to work, but there are positive results from the four projects in which the SIRen process was partially implemented during the iterative 
development of the SIRen framework. Note that using certifications and MCDM tools in a project gives a value in the weighted self-evaluation, which means that a sustainability grading of the actual buildings is included indirectly.

The next step is to use the framework through the entire renovation process in more renovation projects. This is especially needed for the evaluation checklist, which has not yet been used in a real active renovation project. Using knowledge and information within the SIRen researcher and practitioner network and other resources, it should be possible to continually update and improve the framework. Since the framework is openly accessible, transparent, and adaptable, it gives opportunities for replication and adaptation to other countries' conditions.

Author Contributions: Conceptualization, P.W. and K.M.; methodology, P.W.; validation, P.W. and K.M.; formal analysis, P.W. and K.M.; investigation, P.W. and K.M.; resources, P.W. and K.M.; writingoriginal draft preparation, P.W. and K.M.; writing-review and editing, P.W. and K.M.; visualization, P.W.; project administration, K.M.; funding acquisition, K.M. All authors have read and agreed to the published version of the manuscript.

Funding: The research was funded by grant number 2013-1804 SIRen, the national research environment on sustainable integrated renovation, funded by the Swedish Research Council Formas.

Data Availability Statement: Not applicable.

Acknowledgments: We thank the researchers and practitioners within the SIRen network for their innovative discussions and elaboration of the framework and for sharing information on the tools, methods, and routines applied in the renovation process as well as their experiences implementing the SIRen framework in real renovation projects. We also thank the reviewers and editors for providing constructive feedback on the manuscript.

Conflicts of Interest: The authors declare no conflict of interest. 


\section{Appendix A}

Figures A1-A6 show all the statements/questions in the self-evaluation.

Describe how each activity has performed.

Rate quality:

$0=$ not implemented,

1 = qualitative (minimum level),

Checklist for SIRen sustainable renovation process

2 = quantitative (calculation, survey, interview),

$\mathbf{3}=$ detailed.

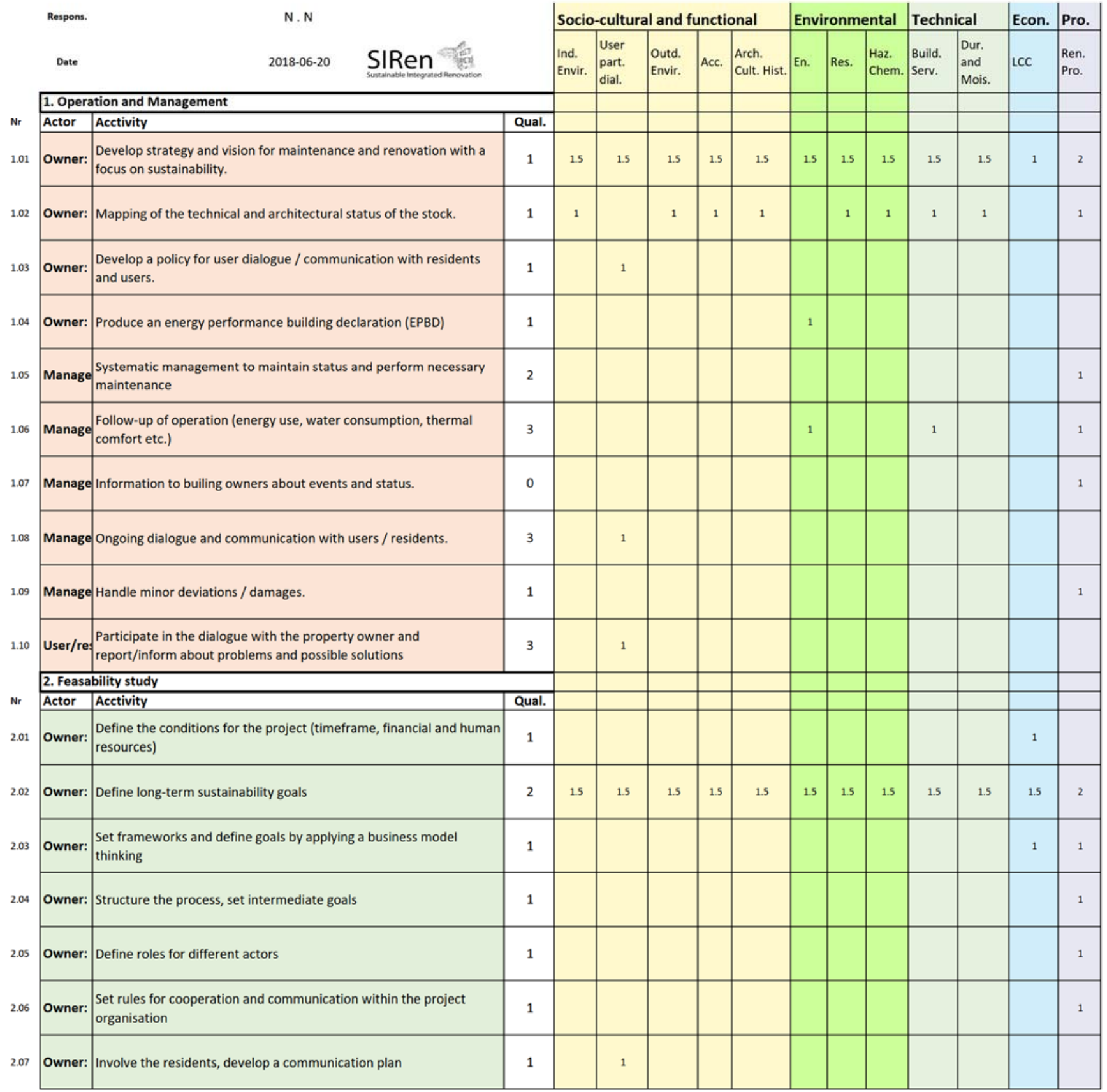

Figure A1. Questions 1.01 to 2.07. 


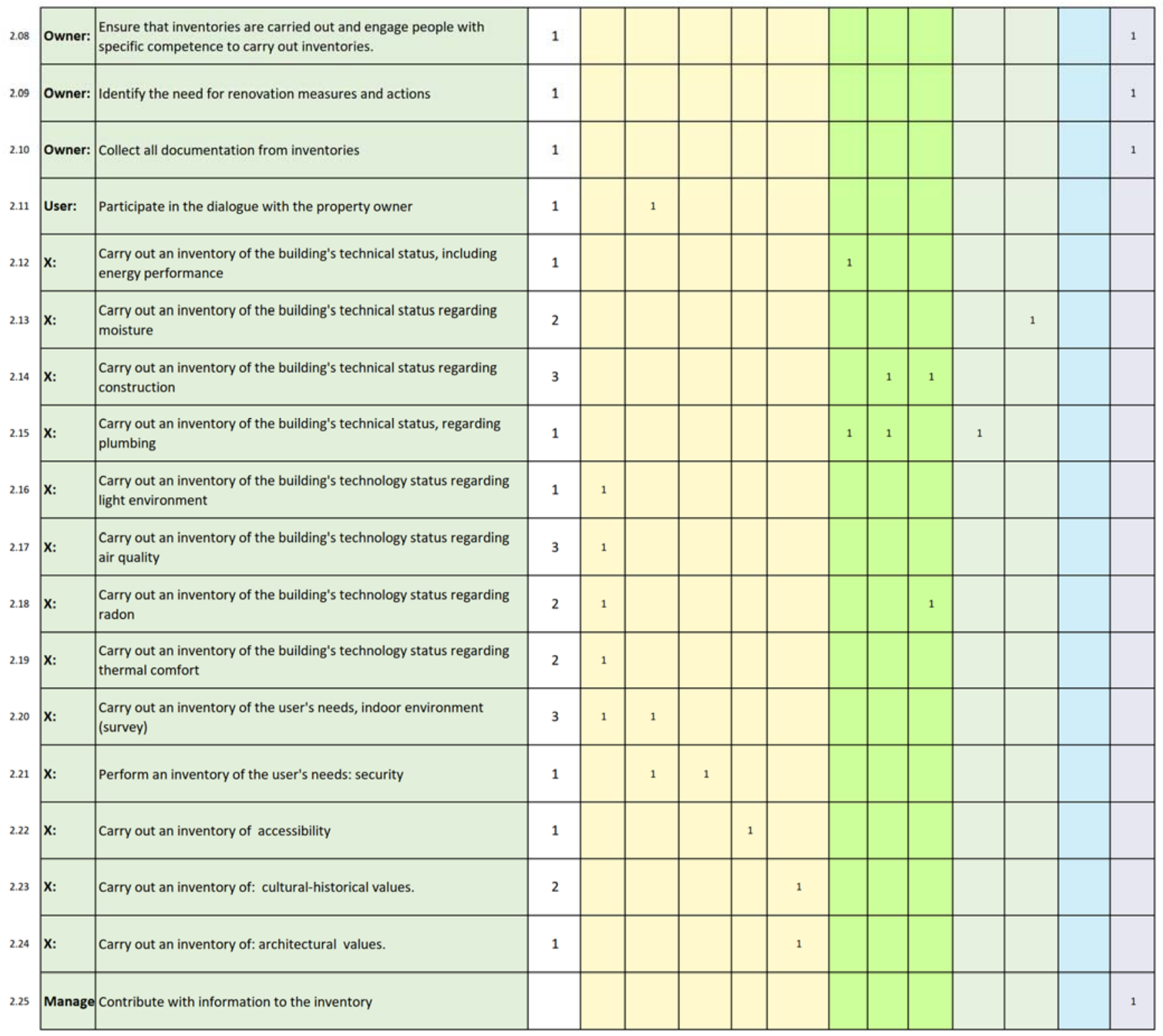

Figure A2. Questions 2.08 to 2.25 . 


\begin{tabular}{|c|c|c|c|c|c|c|c|c|c|c|c|c|c|c|c|}
\hline \multirow[b]{2}{*}{$\mathrm{Nr}$} & \multicolumn{3}{|c|}{ 3. Investigation } & & & & & & & & & & & & \\
\hline & Actor & Acctivity & Qual. & & & & & & & & & & & & \\
\hline 3.01 & Owner: & $\begin{array}{l}\text { Ensure that necessary investigations are made based on the } \\
\text { inventories in the feasibility study, especially with a focus on } \\
\text { sustainability. }\end{array}$ & 1 & 1.5 & 1.5 & 1.5 & 1.5 & 1.5 & 1.5 & 1.5 & 1.5 & 1.5 & 1.5 & 1.5 & 2 \\
\hline 3.02 & Owner: & $\begin{array}{l}\text { Work according to the communication plan to involve } \\
\text { residents/users. }\end{array}$ & 1 & & 1 & & & & & & & & & & \\
\hline 3.03 & Owner: & Collect and compile all documentation from investigations & 2 & & & & & & & & & & & & 1 \\
\hline 3.04 & User: & $\begin{array}{l}\text { Participate in the dialogue with the property owner (eg about rent } \\
\text { increase, mini, midi maxi options) }\end{array}$ & 3 & & 1 & & & & & & & & & & \\
\hline 3.05 & $\mathrm{x}:$ & $\begin{array}{l}\text { Perform investigations based on the inventory such as life cycle cost } \\
\text { calculations (LCC), life cycle assessments (LCA), moisture risks, } \\
\text { structural design, ventilation, energy use, thermal comfort etc for } \\
\text { different design options. }\end{array}$ & 3 & 1 & & & & & 1 & 1 & 1 & 1 & 1 & 1 & \\
\hline 3.06 & $\mathrm{x}$ : & $\begin{array}{l}\text { Perform investigations based on the inventory such as indoor } \\
\text { environment assessments, social impact assessment, cultural } \\
\text { historical assessment. }\end{array}$ & 3 & & 1 & 1 & 1 & 1 & & & & & & & \\
\hline 3.07 & $\mathrm{x}$ : & $\begin{array}{l}\text { Make an inventory of which fixed furnishings and interior surface } \\
\text { layers can be preserved, repaired and what needs to be replaced. }\end{array}$ & 1 & & & & & 1 & & 1 & & & & & \\
\hline 3.08 & Contrac & Assist with cost estimates for different design options (rough) & 1 & & & & & & & & & & & 1 & \\
\hline 3.09 & Supplier & Assist with cost estimates for different design options (rough) & 1 & & & & & & & & & & & 1 & \\
\hline \multirow[t]{2}{*}{3.10} & Manage & Contribute with information to the investigations & 1 & & & & & & & & & & & & 1 \\
\hline & \multicolumn{3}{|c|}{ 4. Programme } & & & & & & & & & & & & \\
\hline $\mathrm{Nr}$ & Actor & Acctivity & Qual. & & & & & & & & & & & & \\
\hline 4.01 & Owner: & $\begin{array}{l}\text { Choose program options and vision based on some form of weighted } \\
\text { sustainability analysis. }\end{array}$ & 2 & 1.5 & 1.5 & 1.5 & 1.5 & 1.5 & 1.5 & 1.5 & 1.5 & 1.5 & 1.5 & 1.5 & 2 \\
\hline 4.02 & Owner: & $\begin{array}{l}\text { Choose which renovation alternative is to be system-designed (based } \\
\text { on investigations in the stage before) }\end{array}$ & 2 & & & & & & & & & & & & 1 \\
\hline 4.03 & Owner: & Collect and compile all documentation & 2 & & & & & & & & & & & & 1 \\
\hline 4.04 & User: & Participate in the dialogue with the property owner & 3 & & 1 & & & & & & & & & & \\
\hline 4.05 & $\mathrm{x}:$ & Development of programs and overall proposals. & 1 & 1 & & 1 & 1 & & & & & & & & 1 \\
\hline 4.06 & $\mathrm{x}:$ & Assist with data for different alternatives. & 1 & & & & & 1 & 1 & 1 & 1 & 1 & 1 & & 1 \\
\hline 4.07 & Contrac & Assist with cost estimates for different design options (finer) & 1 & & & & & & & & & & & 1 & \\
\hline 4.08 & Manage & Contribute with material to the program & 2 & & & & & & & & & & & & 1 \\
\hline
\end{tabular}

Figure A3. Questions 3.01 to 4.08 . 


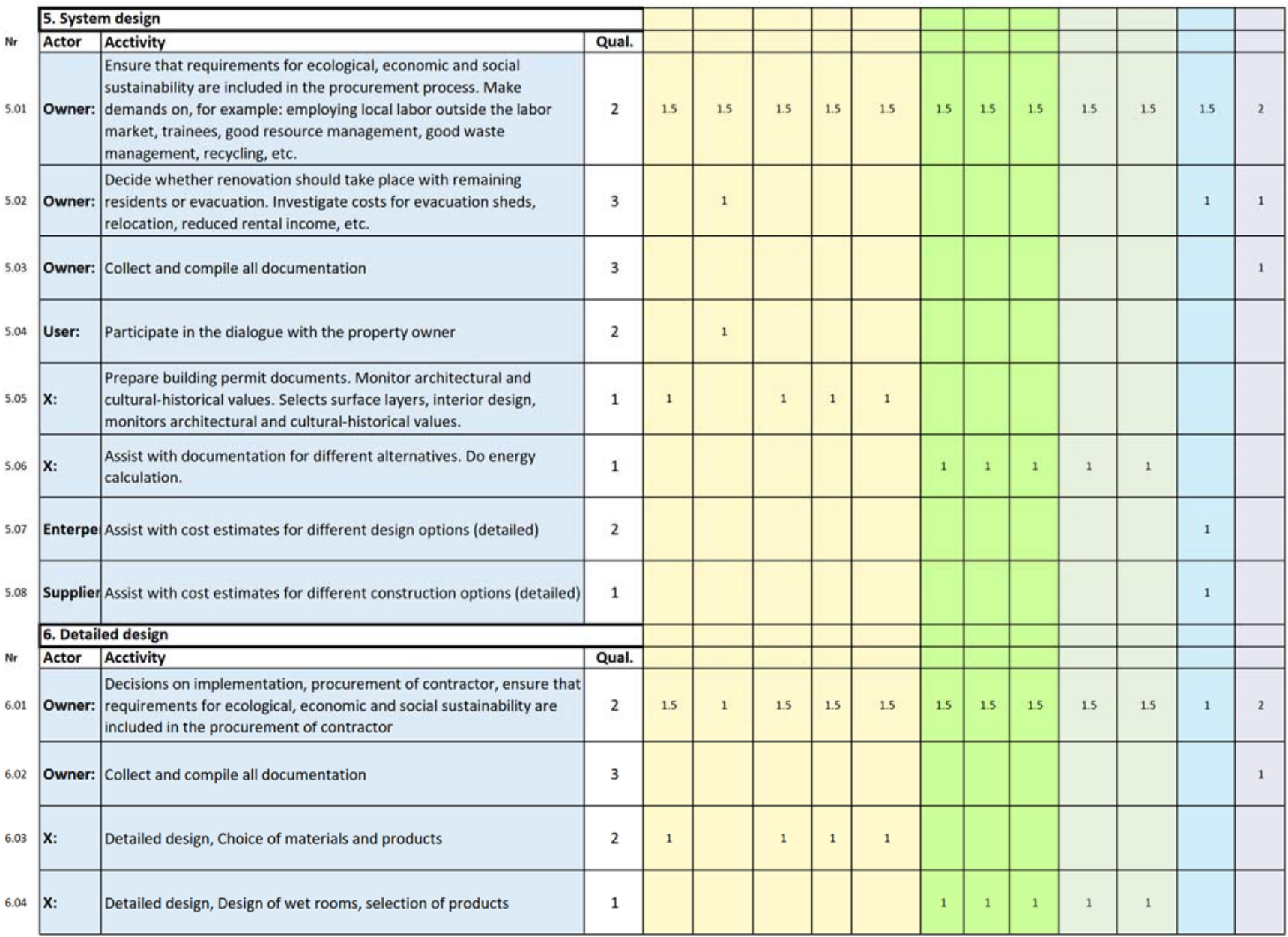

Figure A4. Questions 5.01 to 6.04 . 


\begin{tabular}{|c|c|c|c|c|c|c|c|c|c|c|c|c|c|c|c|}
\hline \multirow[b]{2}{*}{ Nr } & \multicolumn{3}{|c|}{ 7. Reconstruction } & & & & & & & & & & & & \\
\hline & Actor & Acctivity & Qual. & & & & & & & & & & & & \\
\hline 7.01 & Owner: & $\begin{array}{l}\text { Information about the project's sustainability goals and follow-up for } \\
\text { all project participants. Training of cooporate socially employed } \\
\text { workers, . Information meeting with users. Financial monitoring. }\end{array}$ & 2 & 1.5 & 2 & 1.5 & 1.5 & 1.5 & 1.5 & 1.5 & 1.5 & 1.5 & 1.5 & 1 & 2 \\
\hline 7.02 & Owner: & Collect and compile all documentation & 2 & & & & & & & & & & & & 1 \\
\hline 7.03 & User: & Attend information meetings and read distributed information. & 3 & & 1 & & & & & & & & & & \\
\hline 7.04 & Contrac & $\begin{array}{l}\text { Ongoing information during the construction phase. Contact with and } \\
\text { care of tenants during the work. }\end{array}$ & 1 & & 1 & & & & & & & & & & 1 \\
\hline 7.05 & Contrac & $\begin{array}{l}\text { Minimize and sort waste. Follow work environment requirements. } \\
\text { Self-checks eg according to Safe water standards. Ensure that indoor } \\
\text { environmental requirements are met for residents remaining in the } \\
\text { buildings. }\end{array}$ & 1 & 1 & & 1 & & & & 1 & 1 & 1 & 1 & & \\
\hline 7.06 & Supplier & $\begin{array}{l}\text { Minimize and sort waste. Follow work environment requirements. } \\
\text { Self-checks eg according to Safe water standards. }\end{array}$ & 0 & & & & & & & 1 & 1 & 1 & 1 & & \\
\hline 7.07 & $\mathrm{x}:$ & $\begin{array}{l}\text { Follow-up and monitoring of compliance with cultural heritage } \\
\text { requirements /distortion bans and availability. }\end{array}$ & 1 & & & & 1 & 1 & & & & & & & \\
\hline 7.08 & $\mathrm{x}:$ & $\begin{array}{l}\text { Follow-up that specific requirements are met such as fire and } \\
\text { moisture safety. }\end{array}$ & 1 & & & & & & 1 & 1 & 1 & 1 & 1 & & \\
\hline 7.09 & Manage & Ongoing contact with and support to/care of tenants. & 2 & & 1 & & & & & & & & & & \\
\hline & 8. Comm & nissioning & & & & & & & & & & & & & \\
\hline $\mathrm{Nr}$ & Actor & Acctivity & Qual. & & & & & & & & & & & & \\
\hline 8.01 & Owner: & $\begin{array}{l}\text { Ensure that the management organisation and the user/residents are } \\
\text { trained in the functions of the house, especially with a focus on } \\
\text { sustainability aspects (for example, heating, ventilation, cleaning, } \\
\text { maintenance). }\end{array}$ & 3 & 1.5 & 2 & 1.5 & 1.5 & 1.5 & 1.5 & 1.5 & 1.5 & 1.5 & 1.5 & 1 & 2 \\
\hline 8.02 & Owner: & Collect and compile all documentation & 3 & & & & & & & & & & & & 1 \\
\hline 8.03 & User: & Take part in training and information & 2 & & 1 & & & & & & & & & & \\
\hline 8.04 & Contrac & Heating, ventilation and cooling system adjustment. & 2 & 1 & & & & & 1 & & & 1 & & & \\
\hline 8.05 & Contrac & Educates operators and managers in the operation of systems. & 2 & 1 & & & & & 1 & & & 1 & & & 1 \\
\hline 8.06 & Contrac & Educate managers in how the house should be managed. & 2 & 1 & & 1 & 1 & 1 & 1 & 1 & 1 & 1 & 1 & & 1 \\
\hline 8.07 & Manage & Educate users in how the house works and should be cared for. & 3 & 1 & 1 & & & & 1 & & & 1 & & & \\
\hline
\end{tabular}

Figure A5. Questions 7.01 to 8.07 . 


\begin{tabular}{|c|c|c|c|c|c|c|c|c|c|c|c|c|c|c|c|}
\hline & 9. Follow & Nup & & & & & & & & & & & & & \\
\hline or & Aktör & Aktivitet & Kvalitet & & & & & & & & & & & & \\
\hline .01 & Owner: & Process evaluation & 2 & & & & & & & & & & & & 1 \\
\hline 2.02 & Owner: & Evaluation of results & 1 & & & & & & & & & & & & 1 \\
\hline 103 & owner: & Evaluation of economy. & 1 & & & & & & & & & & & 1 & \\
\hline .04 & Owner: & Enerrgy performance declaration (EPDB) & 3 & & & & & & 1 & & & & & & \\
\hline .05 & Owner: & Verification of performance according to building code & 0 & & & & & & 1 & & & & & & \\
\hline .06 & Owner: & Evaluation of how goals for social sustainability were met. & 1 & 1 & 1 & 1 & 1 & & & & & & & & \\
\hline .07 & Owner: & $\begin{array}{l}\text { Evaluation of goals for architectural and cultural historical } \\
\text { sustainability. }\end{array}$ & 2 & & & & & 1 & & & & & & & \\
\hline .08 & Owner: & Evaluation of goals for economic sustainability. & 1 & & & & & & & & & & & 1 & \\
\hline .09 & Owner: & Evaluation of goals for environmental sustainability & 1 & & & & & & 1 & 1 & 1 & 1 & 1 & & \\
\hline 10 & Contrac & Feedback and experience within the organization & 1 & & & & & & & & & & & & 1 \\
\hline .11 & Manage & Follow up information from operation and management & 1 & & & & & & & & & & & & 1 \\
\hline .12 & Manage & Follow up user satisfaction & 1 & & 1 & & & & & & & & & & \\
\hline 13 & User: & Answer the user/residents survey & 1 & & 1 & & & & & & & & & & \\
\hline
\end{tabular}

Figure A6. Questions 9.01 to 9.13.

\section{References}

1. BPIE. Europe's Buildings under the Microscope; Buildings Performance Institute Europe (BPIE): Brussels, Belgium, 2011.

2. Femenías, P.; Fudge, C. Retrofitting the city: Re-use of non-domestic buildings. Int. J. Urban Des. Plan. 2010, 163, 117-126.

3. Tupenaite, L.; Zavadskas, E.K.; Kaklauskas, A.; Turskis, Z.; Seniut, M. Multiple criteria assessment of alternatives for built and human environment renovation. J. Civ. Eng. Manag. 2010, 16, 257-266. [CrossRef]

4. Kamari, A.; Corrao, R.; Kirkegaard, P.H. Sustainability focused decision-making in building renovation. Int. J. Sustain. Built Environ. 2017, 6, 330-350. [CrossRef]

5. Thuvander, L.; Femenias, P.; Mjörnell, K.; Meiling, P. Unveiling the process of sustainable renovation. Sustainability 2012, 4, 1188-1213. [CrossRef]

6. Femenías, P.; Thuvander, L. Strategies for integrated and sustainable renovation: A stronger voice for architectural knowledge. In Architecture and Sustainability: Critical Perspectives for Integrated Design; ACCO Press: Leuven, Belgium; Den Haag, The Netherlands, 2015; pp. 133-140. ISBN 9789462920880.

7. Nielsen, A.; Jensen, R.L.; Larsen, T.S.; Nissen, S.B. Early stage decision support for sustainable building renovation-A review. Build. Environ. 2016, 103, 165-181. [CrossRef]

8. Golić, K.; Kosorić, V.; Lau, S.-K. A framework for early stages of socially sustainable renovation of multifamily buildings with occupants' participation. Sustainability 2020, 12, 8823. [CrossRef]

9. Kamari, A.; Jensen, S.R.; Corrao, R.; Kirkegaard, P.H. A holistic multi-methodology for sustainable renovation. Int. J. Strateg. Prop. Manag. 2019, 23, 50-64. [CrossRef]

10. SIRen Project. Available online: http:/ / www.renoveringscentrum.lth.se/siren/ (accessed on 23 February 2021).

11. Passoni, C.; Marini, A.; Belleri, A.; Menna, C. Redefining the concept of sustainable renovation of buildings: State of the art and an LCT-based design framework. Sustain. Cities Soc. 2021, 64. [CrossRef]

12. Blum, A.; Grant, M. Sustainable neighborhoods: Assessment tools for renovation and development. J. Int. Res. Publ. Ecol. Saf. 2006, 1, 37-54.

13. Kamari, A.; Corrao, R.; Kirkegaard, P.H. Towards the development of a Decision Support System (DSS) for building renovation: Domain Mapping Matrix (DMM) for sustainability renovation criteria and renovation approaches. In Proceedings of the International Conference Catania, Seismic and Energy Renovation for Sustainable Cities, Catania, Italy, 1-3 February 2018. 
14. DGNB System. Criteria Set New Construction Building; Deutsche Gesellschaft für Nachhaltiges Bauen (German Sustainable Building Council): Stuttgart, Germany, 2018.

15. Zhang, H.; Lai Lei, S. An assessment framework for the renovation of existing residential buildings regarding environmental efficiency. Soc. Behav. Sci. 2012, 68, 549-563. [CrossRef]

16. Verfaillie, H.A.; Bidwell, R. Measuring Eco-Efficiency: A Guide to Reporting Company Performance; World Business Council for Sustainable Development: Geneva, Switzerland, 2000.

17. Medineckiene, M. Integrated Decision Making in Civil Engineering, Based on Multi-Criteria Assessment and Buildings' Certification. Ph.D. Thesis, KTH Royal Institute of Technology, Stockholm, Sweden, 2017.

18. BREEAM. Available online: https:/ / www.breeam.com/ (accessed on 23 February 2021).

19. LEED. Available online: https:/ / www.buildinggreen.com/leed (accessed on 23 February 2021).

20. Jensen, P.A.; Maslesa, E. Value based building renovation-A tool for decision-making and evaluation. Build. Environ. 2015, 92, 1-9. [CrossRef]

21. Taherkhani, R.; Hashempour, N.; Lotfi, M. Sustainable-resilient urban revitalization framework: Residential buildings renovation in a historic district. J. Clean. Prod. 2021, 286. [CrossRef]

22. Taillandier, F.; Mora, L.; Breysse, D. Decision support to choose renovation actions in order to reduce house energy-An applied approach. Build. Environ. 2016, 109, 121-134. [CrossRef]

23. Malmqvist, T.; Glaumann, M. Environmental efficiency in residential buildings-A simplified communication approach. Build. Environ. 2009, 44, 937-947. [CrossRef]

24. Gustafsson, M.; Myhren, J.A.; Dotzauer, E.; Gustafsson, M. Life cycle cost of building energy renovation measures, considering future energy production scenarios. Energies 2019, 12, 2719. [CrossRef]

25. Olsson, S.; Malmqvist, T.; Glaumann, M. An approach towards sustainable renovation-A tool for decision support in early project stages. Build. Environ. 2016, 106, 20-32. [CrossRef]

26. Kamari, A.; Laustsen, C.; Peterson, S.; Kirkegaard, P.H. A BIM-based decision support system for the evaluation of holistic renovation scenarios. J. Inf. Technol. Constr. 2018, 23, 354-380.

27. Serrano-Jimenez, A.; Femenías, P.; Thuvander, L. A multi-criteria decision support method towards selecting feasible and sustainable housing renovation strategies. J. Clean. Prod. 2021, 278. [CrossRef]

28. Checkland, P. Soft systems methodology: A thirty year retrospective. Syst. Res. Behav. Sci. 2000, 17, S11-S58. [CrossRef]

29. Mjörnell, K.; Arfvidsson, J.; Sikander, E. A method for including moisture safety in the building process. J. Indoor Built Environ. 2012. [CrossRef]

30. Farsäter, K.; Olander, S. Early decision-making for school building renovation. Facilities 2019, 37, 981-994. [CrossRef]

31. Femenias, P.; Gluch, P.; Mjörnell, K. Challenges for sustainable integrated renovation: Experiences from a Swedish case of a large housing estate. In Retrofit Europe! The Sustainable Built Environment Conference Series; Eindhoven University of Technology: Eindhoven, The Netherlands, 2018.

32. Sustainable Business Report; Report 0204; Swedish Agency for Economic and Regional Growth: Stockholm, Sweden, 2016; ISBN 978-91-87903-71-7. (In Swedish)

33. Olander, S.; Mjörnell, K.; Femenias, P.; Helsing, E.; Wallentén, P. Hållbar renovering ut ett helhetsperspektiv—En antologi från forskningsmiljön SIRen. In SIRen Report 2019:2; Lund University: Lund, Sweden, 2021; (In Swedish). ISBN 978-9188722-65-2.

34. Meurk, S. Praktisk Tillämpning av SIRens Renoveringsprocess, Chapter in an Anthology Published by the SIRen Research Environment. In SIRen Report 2019:2; Lund University: Lund, Sweden, 2019; pp. 21-28. Available online: http:/ / ri.diva-portal. org/smash/get/diva2:1377051/FULLTEXT01.pdf (accessed on 23 February 2021) (In Swedish). ISBN 978-9188722-65-2.

35. ReBo. Available online: https://www.chalmers.se/sv/projekt/Sidor/ReBo.aspx (accessed on 23 February 2021).

36. Renobuild. Available online: https:/ / renobuild.se/ (accessed on 23 February 2021).

37. Mjörnell, K.; Femenías, P.; Annadotter, P. Renovation strategies for multi-residential buildings from the record years in SwedenProfit-driven or socioeconomically responsible? Sustainability 2019, 11, 6988. [CrossRef] 